\title{
A New Pyrrolidone Alkaloid and Other Constituents from Rourea oligophlebia Stems
}

\author{
Thuc Ngoc Dinh (D), ${ }^{1}$ Mai Vu Thi Ha ${ }^{D},{ }^{1}$ Luong Ngo Xuan, ${ }^{2}$ Huan Trinh Thi, ${ }^{2}$ \\ Huong Nguyen Thi, ${ }^{2}$ Mai Nguyen Thi Ngoc, ${ }^{2}$ Giap Tran Huu $\mathbb{D}^{3}$ Oanh Vu Thi Kim ${ }^{3},{ }^{3}$ \\ and Thanh Le Nguyen $\mathbb{D}^{3}$ \\ ${ }^{1}$ Department of Science and Technology Management, Hong Duc University, Thanh Hoa, Vietnam
${ }^{2}$ Faculty of Natural Sciences, Hong Duc University, Thanh Hoa, Vietnam
${ }^{3}$ Institute of Marine Biochemistry (IMBC) and Graduate University of Science and Technology (GUST),
Vietnam Academy of Science and Technology (VAST), 18 Hoang Quoc Viet, Caugiay, Hanoi, Vietnam
}

Correspondence should be addressed to Thuc Ngoc Dinh; dinhngocthuc@hdu.edu.vn

Received 24 December 2020; Accepted 6 August 2021; Published 18 August 2021

Academic Editor: Angela Patti

Copyright (c) 2021 Thuc Ngoc Dinh et al. This is an open access article distributed under the Creative Commons Attribution License, which permits unrestricted use, distribution, and reproduction in any medium, provided the original work is properly cited.

\begin{abstract}
Phytochemical study of Rourea oligophlebia stems led to the isolation of a new 2-pyrrolidone alkaloid $(R, S)$ - $N$ - $(5$-hydroxylpyrrolidin-2-one-1-yl)acetamide (1), together with 14 known compounds including friedelin (2), friedanol (3), taraxerol (4), vanillin (5), coniferyl aldehyde (6), apigenin (7), $7 \alpha$-hydroxy-3 $\beta$-sitosterol (8), coniferyl alcohol (9), scopoletin (10), emodin (11), protocatechuic acid (12), catechin (13), procyanidin A1 (14), and (E)-2,3,5,4'-tetrahydroxystilbene-2- $\beta$-D-glucoside (15). Several isolated compounds were evaluated for cytotoxicity and antimicrobial activity. Compound $\mathbf{1 1}$ exhibited good antimicrobial activity on Gram (+) strains and moderate cytotoxicity against KB, Hep-G2, and LU cancer cell lines. Compounds $\mathbf{6}$ and 8-10 showed selective activity on HepG-2 and MCF-7 over KB and LU cancer cell lines, while compound 7 exhibited similar effects on $\mathrm{KB}, \mathrm{HepG}-2$, and MCF-7 cell lines with $\mathrm{IC}_{50}$ values of $36.46 \pm 0.81,32.00 \pm 0.58$, and $32.03 \pm 0.61 \mu \mathrm{g} / \mathrm{mL}$, respectively.
\end{abstract}

\section{Introduction}

The genus of Rourea is a group of climbing shrubs belonging to the family of Connaraceae which are widely distributed in the Amazon, Pacific region, Africa, and Asia [1]. Chemical investigations have revealed that Rourea species contain a substantial number of biologically active constituents, including flavonoids, phytosteroids, triterpenes, lipids, phenolic acids, and coumarins [1-6]. The Rourea plant extracts and their active components exhibited interesting biological activities such as hypoglycemic activity $[1,5,7]$, antibacterial activity $[1,8]$, antinociceptive activity [9], antiplasmodial activity [3, 10], and antioxidant activity $[1,4,8]$. Rourea oligophlebia Merr. is a species found on mountains of central provinces of Vietnam. According to folk medicine, $R$. oligophlebia stems have been used for the treatment of bleeding and bone fractures [11]. A preliminary study of $R$. oligophlebia revealed the presence of triterpene, sterol, and phenolic constituents [12]. In this study, we described the isolation and identification of a new pyrrolidone alkaloid $(R, S)$ $\mathrm{N}$-(5-hydroxyl-pyrrolidin-2-one-1-yl)acetamide (1) (Figure 1) and fourteen known compounds including friedelin (2), friedanol (3), taraxerol (4), vanillin (5), coniferyl aldehyde (6), apigenin (7), $7 \alpha$-hydroxy-3 $\beta$-sitosterol (8), coniferyl alcohol (9), scopoletin (10), emodin (11), protocatechuic acid (12), catechin (13), procyanidin A1 (14), and (E)-2,3,5,4'-tetrahydroxystilbene-2- $\beta$-D-glucoside (15) from the stems of $R$. oligophlebia (Figure S1). The isolated compounds were evaluated for antimicrobial activity and cytotoxicity.

\section{Materials and Methods}

2.1. General Experimental Procedures. The NMR data including ${ }^{1} \mathrm{H}-\mathrm{NMR},{ }^{13} \mathrm{C}-\mathrm{NMR},{ }^{15} \mathrm{~N}-\mathrm{NMR}, \mathrm{HSQC}$, and HMBC spectra were recorded by a Bruker AM500 FT-NMR 


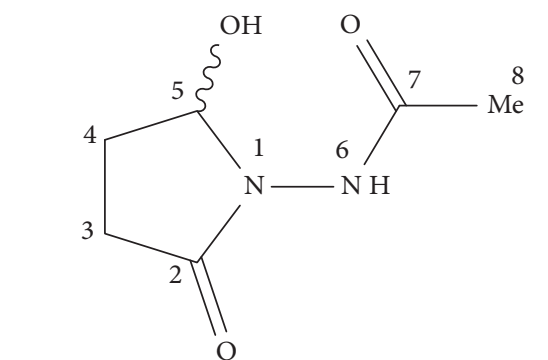

$N$ - (5-Hydroxy-pyrrolidin-2-one-1-yl)acetamide(1)

Figure 1: Structure of new compound isolated from R. oligophlebia.

spectrometer using TMS as an internal standard. The HRESI-MS was obtained using an Agilent 6530 Accurate Mass Q-TOF LC/MS system. Column chromatography (CC) was performed on silica gel (Merck, 230-400 mesh) or Sephadex LH-20 (Sigma Aldrich). Thin layer chromatography used precoated silica gel plates (Merck $60 \mathrm{~F}_{254}$ ). Compounds were visualized by spraying with $10 \%$ aqueous $\mathrm{H}_{2} \mathrm{SO}_{4}$.

2.2. Plant Materials. The plant stems were collected from the Ben En National Park, Thanh Hoa province, Vietnam, in 2018. The plant was identified by Dr. Do Ngoc Dai, Nghe An University of Economics, as Rourea oligophlebia Merr. (Connaraceae). A voucher specimen (MT-202) was deposited at Hong Duc University, Faculty of Natural Sciences.

2.3. Extraction and Isolation. The stem powder $(5.3 \mathrm{~kg})$ of Rourea oligophlebia was extracted successively with $n$-hexane, ethyl acetate, and methanol (12 L $\times 3$ times, 24 hours/time) at room temperature. The combined extracts were evaporated in vacuo to obtain $n$-hexane residue $(17.6 \mathrm{~g})$, ethyl acetate residue $(10 \mathrm{~g})$, and $\mathrm{MeOH}$ residue $(300 \mathrm{~g})$, respectively.

The ethyl acetate residue $(10 \mathrm{~g})$ was separated on the silica gel CC, eluted with $n$-hexane/ethyl acetate gradient (0-100\% ethyl acetate) to afford 15 fractions E1-E15. Compounds 2 (15 mg), 3 (5.5 mg), and 4 (4.5 mg) were obtained from E1 fraction (0.2 g), E3 fraction (0.12 g), and E4 fraction (0.15 g), respectively, by crystallization in $n$-hexane. Fraction E10 (0.5 g) was fractionated by Sephadex CC, eluted with $\mathrm{CH}_{2} \mathrm{Cl}_{2} / \mathrm{MeOH}$ $(1 / 9, \mathrm{v} / \mathrm{v})$ to afford 4 subfractions E10.1-E10.4. Subfraction E10.2 (17 mg) was purified by preparative TLC using $\mathrm{CH}_{2} \mathrm{Cl}_{2} /$ $\mathrm{MeOH}(95 / 5, \mathrm{v} / \mathrm{v})$ as eluent to yield $5(2 \mathrm{mg})$ and $6(2.5 \mathrm{mg})$. Fraction E10.3 (25 mg) was purified by silica gel CC, eluted with $\mathrm{CH}_{2} \mathrm{Cl}_{2} / \mathrm{MeOH}(95 / 5$, v/v) to obtain compound 7 (15 mg). Fraction E12 (0.9 g) was fractionated by Sephadex CC, eluted with $\mathrm{CH}_{2} \mathrm{Cl}_{2} / \mathrm{MeOH}(1 / 9, \mathrm{v} / \mathrm{v})$ to give 3 subfractions E12.1-12.3. Compound 8 (6.1 mg) was obtained from E12.1 fraction ( $85 \mathrm{mg}$ ) by crystallization in $n$-hexane. Fraction E12.2 (30 mg) was chromatographed by silica gel $\mathrm{CC}$, eluted with $\mathrm{CH}_{2} \mathrm{Cl}_{2}$ / $\mathrm{MeOH}(95 / 5, \mathrm{v} / \mathrm{v})$ to yield 9 (15 mg). Fraction E13 (0.7 g) was purified by Sephadex CC, eluted with $\mathrm{CH}_{2} \mathrm{Cl}_{2} / \mathrm{MeOH}(1 / 9)$, to give two subfractions E13.1-E13.2. Subfraction E13.2 (20 mg) was purified by preparative TLC using $\mathrm{CH}_{2} \mathrm{Cl}_{2} / \mathrm{MeOH}(95 / 5$, v/ v) as an eluant to afford compound $\mathbf{1 0}(3 \mathrm{mg})$. The $\mathrm{MeOH}$ extract $(300 \mathrm{~g})$ was chromatographed on a silica gel CC and eluted with a gradient solvent system of $n$-hexane-ethyl acetate (100:1-0:1, v/v) to afford 14 fractions M1-M14, respectively. Fraction M6 (0.8 g) was separated by Sephadex LH-20 CC eluting with $\mathrm{CH}_{2} \mathrm{Cl}_{2} / \mathrm{MeOH}(1 / 9, \mathrm{v} / \mathrm{v})$ to yield compound 11 (7 mg). Fraction M12 (0.6 g) was purified by Sephadex LH-20 $\mathrm{CC}$ and eluted with $\mathrm{CH}_{2} \mathrm{Cl}_{2} / \mathrm{MeOH}(1 / 9$, v/v) to afford compound $12(6 \mathrm{mg})$. Compound $13(12 \mathrm{mg})$ was obtained from M13 fraction $(1.1 \mathrm{~g})$ by purification on Sephadex LH-20 CC, eluted with $\mathrm{CH}_{2} \mathrm{Cl}_{2} / \mathrm{MeOH}(1 / 9, \mathrm{v} / \mathrm{v})$. Fraction M14 was purified by silica gel CC and eluted with $\mathrm{CH}_{2} \mathrm{Cl}_{2}$ /acetone $(9: 1, \mathrm{v} / \mathrm{v})$ to give 3 fractions M14.1-M14.3. Fraction M14.1 (0.5 g) was subjected to a Sephadex LH-20 CC and eluted with $\mathrm{CH}_{2} \mathrm{Cl}_{2}$ / $\mathrm{MeOH}(1 / 9, \mathrm{v} / \mathrm{v})$ to yield $14(5.7 \mathrm{mg})$. Fraction M14.2 (2 g) was separated by Sephadex LH-20 CC and eluted with $\mathrm{CH}_{2} \mathrm{Cl}_{2}$ / $\mathrm{MeOH}(1 / 9, \mathrm{v} / \mathrm{v})$ to give 3 fractions M14.2.1-M14.2.3. Fraction M14.2.1 (0.45 g) was purified by Sephadex LH-20 CC, followed by separation with silica gel $\mathrm{CC}$, eluted with $\mathrm{CH}_{2} \mathrm{Cl}_{2} / \mathrm{MeOH}$ (9/ $1, \mathrm{v} / \mathrm{v})$ to yield compound $\mathbf{1}(20 \mathrm{mg})$. Fraction M14.2 (0.28 g) was subjected to silica gel CC eluted with $\mathrm{CH}_{2} \mathrm{Cl}_{2} / \mathrm{MeOH}(9 / 1$, $\mathrm{v} / \mathrm{v})$ to yield 2 subfractions M14.2.2.1-M14.2.2.2. Fraction M14.2.2.2 (84 mg) was purified by Sephadex LH-20 CC, eluting with $\mathrm{CH}_{2} \mathrm{Cl}_{2} / \mathrm{MeOH}(1 / 9, \mathrm{v} / \mathrm{v})$ to yield compound $15(7 \mathrm{mg})$.

$(R, S)-N$-(5-Hydroxyl-pyrrolidin-2-one-1-yl)acetamide (1): colorless oil; $[\alpha]_{D}^{25} \sim 0(c 0.4, \mathrm{MeOH}) ; \mathrm{IR} \nu_{\max }(\mathrm{KBr}) 3239$, 3022, 1706, 1664, $1211 \mathrm{~cm}^{-1}$; HR-ESI-MS (positive-ion mode) $m / z \quad 141.0673 \quad\left[\left(\mathrm{M}-\mathrm{H}_{2} \mathrm{O}\right)+\mathrm{H}\right]^{+} \quad$ (calcd. for $\mathrm{C}_{6} \mathrm{H}_{9} \mathrm{~N}_{2} \mathrm{O}_{2}{ }^{+}, 141.0659$ ); ${ }^{1} \mathrm{H}$ and ${ }^{13} \mathrm{C}-\mathrm{NMR}$ data (Table 1).

2.4. Cytotoxicity Assay. The cytotoxicity assays were carried out in triplicate against KB, HepG-2, LU, and MCF-7 cell lines (American Type and Culture Collection, ATCC). Cells were maintained in Dulbecco's D-MEM medium, supplemented with $10 \%$ fetal calf serum, L-glutamine $(2 \mathrm{mM})$, penicillin $\mathrm{G}(100 \mathrm{UI} / \mathrm{mL})$, streptomycin $(100 \mu \mathrm{g} / \mathrm{mL})$, and gentamicin $(10 \mu \mathrm{g} / \mathrm{mL})$. Stock solutions of compounds were prepared in $\mathrm{DMSO} / \mathrm{H}_{2} \mathrm{O}(1 / 9)$, and the cytotoxicity assays were carried out against cancer cell lines $\left(3 \times 10^{3}\right.$ cells $\left./ \mathrm{mL}\right)$ using a modification of the published method [13]. After $72 \mathrm{~h}$ of incubation at $37^{\circ} \mathrm{C}$ in air/ $/ \mathrm{CO}_{2}(95: 5)$ with or without test compounds, cell growth was estimated by colorimetric measurement at $540 \mathrm{~nm}$ with a Titertek Multiskan photometer. Ellipticine was used as a positive compound.

2.5. Antimicrobial Assay. The antimicrobial activity was evaluated by the microdilution method previously described by Hadacek [14] and expressed as IC $_{50}$ (50\% inhibitory concentration) values. Six bacterial strains and a fungus were used for the test: 3 strains of Gram (+) bacteria: Staphylococcus aureus ATCC 13709, Bacillus subtilis ATCC 6633, and Lactobacillus fermentum N4; 3 strains of Gram (-) bacteria: Salmonella enterica ATCC12228, Escherichia coli ATCC 25922, and Pseudomonas aeruginosa ATCC 15442; fungus: Candida albicans ATCC 10231. Bacterial solutions with a concentration of $5 \times 10^{5} \mathrm{CFU} / \mathrm{ml}$ and a fungal solution with a concentration of $1 \times 10^{3} \mathrm{CFU} / \mathrm{ml}$ were prepared. The isolated compounds were diluted in DMSO at the following dilution concentrations: $128,64,32,16,8$, and $4 \mu \mathrm{g} / \mathrm{mL}$. The positive controls were ampicillin for Gram (+) bacterial strains, 
Table 1: ${ }^{1} \mathrm{H}$ and ${ }^{13} \mathrm{C}$ NMR data of $\mathbf{1}$.

\begin{tabular}{|c|c|c|c|c|}
\hline \multirow{2}{*}{$\mathrm{C}$} & \multicolumn{2}{|c|}{1 (acetone- $d_{6}$ ) } & \multicolumn{2}{|c|}{$1\left(\mathrm{MeOH}-d_{4}\right)$} \\
\hline & $\delta_{\mathrm{C}}{ }^{\mathrm{a}}$ & $\delta_{\mathrm{H}}^{\mathrm{b}}(\mathrm{m}, J, \mathrm{~Hz})$ & $\delta_{\mathrm{C}}{ }^{\mathrm{a}}$ & $\delta_{\mathrm{H}}^{\mathrm{b}}(\mathrm{m}, J, \mathrm{~Hz})$ \\
\hline 2 & 172.4 & - & 175.0 & - \\
\hline 3 & 27.3 & $\begin{array}{l}2.46-2.39(\mathrm{~m}, \mathrm{H}-3 \mathrm{a}) \\
2.38-2.32(\mathrm{~m}, \mathrm{H}-3 \mathrm{~b}) \\
\end{array}$ & 27.8 & $\begin{array}{l}2.59-2.50(\mathrm{~m}, \mathrm{H}-3 \mathrm{a}) \\
2.38-2.32(\mathrm{~m}, \mathrm{H}-3 \mathrm{~b}) \\
\end{array}$ \\
\hline 4 & 27.1 & $\begin{array}{l}2.27-2.21(\mathrm{~m}, \mathrm{H}-4 \mathrm{a}) \\
1.88-1.81(\mathrm{~m}, \mathrm{H}-4 \mathrm{~b})\end{array}$ & 27.1 & $\begin{array}{l}2.27-2.21(\mathrm{~m}, \mathrm{H} 4 \mathrm{a}) \\
1.88-1.81(\mathrm{~m}, \mathrm{H} 4 \mathrm{~b})\end{array}$ \\
\hline 5 & 83.4 & $5.22(\mathrm{br} \mathrm{s})$ & 84.2 & $5.22(\mathrm{dd}, J=3.5 \mathrm{~Hz}, 6.5 \mathrm{~Hz})$ \\
\hline 7 & 169.6 & - & 172.1 & - \\
\hline 8 & 20.6 & $1.96(\mathrm{~s})$ & 20.5 & $2.06(\mathrm{~s})$ \\
\hline $\mathrm{OH}$ & - & $5.47(\mathrm{br} \mathrm{d}, J=5.5)$ & - & - \\
\hline $\mathrm{NH}$ & - & $9.16(\mathrm{br} \mathrm{s})$ & - & - \\
\hline
\end{tabular}

cefotaxime for Gram (-) bacterial strains, and nystatin for fungus. $\mathrm{IC}_{50}$ values were determined based on the measured turbidity by optical Biotech spectra and raw data software.

\section{Results and Discussion}

3.1. Structure Elucidation. Compound $\mathbf{1}$ was isolated as colorless oil. Its molecular formula of $\mathbf{1}$ was deduced as $\mathrm{C}_{6} \mathrm{H}_{10} \mathrm{~N}_{2} \mathrm{O}_{3}$ from the $\left[\left(\mathrm{M}-\mathrm{H}_{2} \mathrm{O}\right)+\mathrm{H}\right]^{+}$peak at $\mathrm{m} / z 141.0673\left(\mathrm{C}_{6} \mathrm{H}_{9} \mathrm{~N}_{2} \mathrm{O}_{2}\right.$, calcd. for 141.0659) in the positive-ion HR-ESI-MS spectrum (Figure S2). The molecular formula of $\mathrm{C}_{6} \mathrm{H}_{10} \mathrm{~N}_{2} \mathrm{O}_{3}$ was further confirmed by combined ${ }^{1} \mathrm{H},{ }^{13} \mathrm{C}$, and ${ }^{15} \mathrm{~N}-\mathrm{NMR}$ spectra as ten protons, six carbons, and two signals of nitrogen $\left(\delta_{\mathrm{N}} 199.99\right.$ and 165.86) were observed (Figure S3). The IR spectrum suggested that 1 contained carbonyl amide groups $\left(1706,1664 \mathrm{~cm}^{-1}\right)$ and hydroxyl and amine groups $\left(3239 \mathrm{~cm}^{-1}\right)$ (Figure 44$)$, which appeared in the ${ }^{1} \mathrm{H}-\mathrm{NMR}$ spectrum (in acetone- $d_{6}$ ) at $\delta_{\mathrm{H}} 5.47$ (br d, $J=5.5 \mathrm{~Hz}$ ) and 9.16 (br s), respectively (Figure S5). The ${ }^{1} \mathrm{H}-\mathrm{NMR}$ spectrum (in $\mathrm{MeOH}-d_{4}$ ) showed signals of an oxymethine group at $\delta_{\mathrm{H}} 5.22(1 \mathrm{H}, \mathrm{dd}, J=3.5,6.5 \mathrm{~Hz}, \mathrm{H}-5)$, two methylene groups ( $\mathrm{H}-3, \mathrm{H}-4)$, and a methyl singlet of an acetyl group at $\delta_{\mathrm{H}} 2.06(3 \mathrm{H}, \mathrm{s}, \mathrm{H}-8)$ (Figure S6). The ${ }^{13} \mathrm{C}-\mathrm{NMR}$ spectrum of 1 displayed six carbon signals including two signals of carbonyl group at $\delta_{\mathrm{C}} 175.0(\mathrm{C}-2)$ and $172.1(\mathrm{C}-7)$, an oxymethine group at $\delta_{\mathrm{C}} 84.2(\mathrm{C}-5)$, two methylene groups at $\delta_{\mathrm{C}}$ $27.1(\mathrm{C}-3)$ and $27.8(\mathrm{C}-4)$, and a methyl signal at $\delta_{\mathrm{C}} 20.5(\mathrm{C}-8)$ (Figures $\mathrm{S} 7-\mathrm{S} 10$ ). The HMBC cross-peaks (in acetone- $d_{6}$ ) of the hydroxyl group $\left(\delta_{\mathrm{H}} 5.47\right)$ to $\mathrm{C}-5\left(\delta_{\mathrm{C}} 84.2\right)$ confirmed the free hydroxyl group was placed at $\mathrm{C}-5$ position. In the HMBC spectrum (in $\left.\mathrm{MeOH}-d_{4}\right)$, the correlations of $\mathrm{H}-3\left(\delta_{\mathrm{H}} 2.59-2.50\right.$ and $2.38-2.32), \mathrm{H}-4\left(\delta_{\mathrm{H}} 2.27-2.21\right.$ and $\left.1.88-1.81\right)$, and $\mathrm{H}-5\left(\delta_{\mathrm{H}}\right.$ $5.47)$ to $\mathrm{C}-2\left(\delta_{\mathrm{C}} 175.0\right)$ suggested a 5-hydroxy-pyrrolidin-2-one moiety in the structure of $\mathbf{1}$ (Figures S11 and S12). In addition, methyl protons $\mathrm{H}-8\left(\delta_{\mathrm{H}} 2.06\right)$ have only correlated with the carbonyl carbon C-7 ( $\left.\delta_{\mathrm{C}} 172.1\right)$ (Figure 2). Based on the optical rotation value of nearly zero and the $\mathrm{CD}$ spectrum (Figure S13), compound $\mathbf{1}$ may be regarded as a racemate. Therefore, the structure of $\mathbf{1}$ was assigned as $(R, S)-N$-(5-hydroxyl-pyrrolidin2-one-1-yl)acetamide. It is noted that alkaloids containing 5hydroxy-2-pyrrolidone fragment were rarely found in nature. To our knowledge, only few examples are brachystemidine D isolated from Brachystemma calycinum [15], longistrobin and isolongistrobin from Macrorungia longistrabus [16], and lepiota

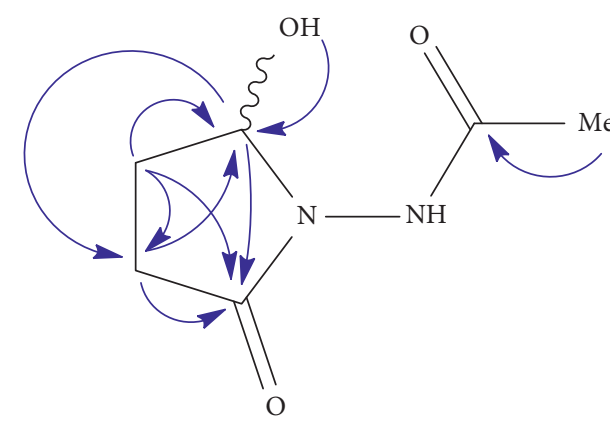

Figure 2: Key HMBC correlations of the new compound 1.

and (R)-5-hydroxypyrrolidin-2-one from the mushroom Macrolepiota neomastoidea [17].

The known compounds were elucidated as friedelin (2), friedanol (3) [12], taraxerol (4) [18], vanillin (5), coniferyl aldehyde (6) [19], apigenin (7) [20], $7 \alpha$-hydroxy-3 $\beta$-sitosterol (8) [21], coniferyl alcohol (9) [22], scopoletin (10) [23], emodin (11) [24], protocatechuic acid (12), catechin (13) [25], procyanidin A1 (14) [26], and (E)-2,3,5,''-tetrahydroxystilbene-2- $\beta$-D-glucoside (15) [27]. Compounds 2-3, 6-9, 11-12, and 15 were reported for the first time from Rourea genus.

3.2. Biological Activities. Several isolated compounds were evaluated for antimicrobial activity and cytotoxicity. Only emodin (11) showed good antimicrobial activity against Gram (+) strains S. aureus, B. subtilis, and L. fermentum with $\mathrm{IC}_{50}$ values of $4.51,15.83$, and $28.94 \mu \mathrm{g} / \mathrm{mL}$, respectively, but exhibited no activity against Gram (-) strains and fungus at the concentration of $128 \mu \mathrm{g} / \mathrm{mL}$. Other compounds were also inactive $\left(\mathrm{IC}_{50}>128 \mu \mathrm{g} / \mathrm{mL}\right)$ in antimicrobial activity test. The cytotoxicity of isolated compounds was evaluated against KB, HepG-2, LU, and MCF-7 cancer cell lines (Table S1). Compounds $\mathbf{6}$ and 8-10 showed selective activity on HepG-2 and MCF-7 with $\mathrm{IC}_{50}$ ranging from $18.73 \pm 0.40 \mu \mathrm{g} / \mathrm{mL}$ to $43.63 \pm 0.90 \mu \mathrm{g} / \mathrm{mL}$ over $\mathrm{KB}$ and LU cancer cell lines. Compound 7 exhibited similar effect on KB, HepG-2 and MCF-7 cell lines. Among the tested compounds, emodin (11) had the best cytotoxicity on LU cancer cell line with $\mathrm{IC}_{50}$ values of $21.04 \pm 0.52 \mu \mathrm{g} / \mathrm{mL}$, respectively. 


\section{Conclusions}

In conclusion, fifteen compounds were isolated from the stems of Rourea oligophlebia, among which a new alkaloid $(R, S)$-N-(5-hydroxyl-pyrrolidin-2-one-1-yl)acetamide (1) was identified along with fourteen known compounds 2-15. Compound 11 showed good antimicrobial activity on Gram (+) strains and moderate cytotoxicity against KB, Hep-G2, and LU-1 cell lines. Compounds $\mathbf{6}$ and 8-10 showed selective activity on HepG-2 and MCF-7 over KB and LU cancer cell lines, while compound 7 was moderately active on $\mathrm{KB}$, HepG-2, and MCF-7 cell lines.

\section{Data Availability}

The data used to support the findings of this study are included within the supplementary materials.

\section{Conflicts of Interest}

The authors declare that there are no conflicts of interest regarding the publication of this paper.

\section{Acknowledgments}

This research was funded by the Vietnam National Foundation for Science and Technology Development (NAFOSTED) under grant number 104.01-2018.08.

\section{Supplementary Materials}

HR-ESI-MS, IR, CD, and NMR spectra of compound $\mathbf{1}$ associated with this article (). (Supplementary Materials)

\section{References}

[1] C. P. Osman, Z. Zahari, M. I. Adenan, and R. M. Zohdi, “A review on traditional uses, phytochemistry, and pharmacology of the genus Rourea," Journal of Applied Pharmaceutical Science, vol. 9, no. 9, pp. 125-131, 2019.

[2] H. N. Ngoc, S. Löffler, D. T. Nghiem, T. L. G. Pham, H. Stuppner, and M. Ganzera, "Phytochemical study of Rourea minor stems and the analysis of therein contained bergenin and catechin derivatives by capillary electrophoresis," zJournal, vol. 149, Article ID 104063, 2019.

[3] Z. D. He, C. Y. Ma, G. T. Tan et al., "Rourinoside and rouremin, antimalarial constituents from Rourea minor," Phytochemistry, vol. 67, no. 13, pp. 1378-1384, 2006.

[4] M. Kalegari, C. A. B. Gemin, G. A. Silva et al., "Chemical composition, antioxidant activity and hepatoprotective potential of Rourea induta Planch. (Connaraceae) against CCl4induced liver injury in female rats," Nutrition, vol. 30, no. 6, pp. 713-718, 2014.

[5] M. M. Laikowski, P. R. Santos, D. M. Souza et al., "Rourea cuspidata: chemical composition and hypoglycemic activity," Asian Pacific Journal of Tropical Biomedicine, vol. 7, no. 8, pp. 712-718, 2017.

[6] P. V. De Oliveira, R. P. L. Lemos, and L. M. Conserva, "Chemical constituents of Rourea doniana," Brazilian Journal of Pharmacognosy, vol. 22, no. 2, pp. 451-454, 2012.

[7] A. Chaudhary, A. Bhandari, and A. Pandurangan, "Antihyperglycemic potential of Rourea minor roots in streptozotocin (STZ) induced diabetic rats," International Journal of Pharmaceutical Research, vol. 4, no. 1, pp. 59-62, 2012.

[8] M. Kalegari, M. D. Miguel, A. F. Philippsen et al., "Antibacterial, allelopathic and antioxidant activity of extracts and compounds from Rourea induta Planch. (Connaraceae)," Journal of Applied Pharmaceutical Science, vol. 2, no. 9, pp. 61-66, 2012.

[9] M. Kalegari, M. L. Cerutti, S. J. M. Júnior et al., "Chemical composition and antinociceptive effect of aqueous extract from Rourea induta Planch. leaves in acute and chronic pain models," Journal of Ethnopharmacology, vol. 153, no. 3, pp. 801-809, 2014.

[10] J. Bero, M. Frédérich, and J. Quetin-Leclercq, “Antimalarial compounds isolated from plants used in traditional medicine," Journal of Pharmacy and Pharmacology, vol. 61, no. 11, pp. 1401-1433, 2009.

[11] V. V. Chi, Dictionary of Vietnamese Medicinal Plants, Medical Publisher, Hanoi, Vietnam, 2012.

[12] D. N. Thuc, V. T. Thuy, V. T. H. Mai, L. N. Thanh, V. V. Quan, Chemical constituents from ethyl acetate extract of the stems of Rourea oligophlebia Merr." Vietnam Journal of Chemistry, vol. 58, no. 3, pp. 298-301, 2020.

[13] T. Mosmann, "Rapid colorimetric assay for cellular growth and survival: application to proliferation and cytotoxicity assays," Journal of Immunological Methods, vol. 65, no. 1-2, pp. 59-63, 1983.

[14] F. Hadacek and H. Greger, "Testing of antifungal natural products: methodologies, comparability of results and assay choice," Phytochemical Analysis, vol. 11, no. 3, pp. 137-147, 2000.

[15] Y. X. Cheng, J. Zhou, N. H. Tan et al., "Isolation and characterization of brachystemidines A-E, novel alkaloids from Brachystemma calycinum," Journal of Natural Products, vol. 65, no. 5, pp. 750-752, 2002.

[16] M. A. Wuonola and R. B. Woodward, "Imidazole alkaloids of Macrorungia longistrobus: revised structures and total syntheses," Tetrahedron, vol. 32, no. 10, pp. 1085-1095, 1976.

[17] K. H. Kim, I. K. Lee, K. M. Park, W. K. Kim, and K. R. Lee, "Isolation of $\gamma$-lactam alkaloids from the Macrolepiota neomastoidea," Bulletin of the Korean Chemical Society, vol. 29, no. 8, pp. 1591-1593, 2008.

[18] Y. C. Koay, K. C. Wong, H. Osman, I. M. S. Eldeen, and M. Z. Asmawi, "Chemical constituents and biological activities of Strobilanthes crispus L." Records of Natural Products, vol. 7, no. 1, pp. 59-64, 2013.

[19] L. Moujir, A. M. L. Seca, A. M. S. Silva, and M. C. Barreto, "Cytotoxic activity of diterpenes and extracts of Juniperus brevifolia," Planta Medica, vol. 74, no. 7, p. 751, 2008.

[20] T. Ersöz, Ü. Ş. Harput, I. Saracoğlu, I. Çaliş, and Y. Ogihara, "Phenolic compounds from Scutellaria pontica," Turkish Journal of Chemistry, vol. 26, no. 4, pp. 581-588, 2002.

[21] C. C. Zhao, J. H. Shao, X. Li, J. Xu, and P. Zhang, "Antimicrobial constituents from fruits of Ailanthus altissima Swingle," Archives of Pharmacal Research, vol. 28, no. 10, pp. 1147-1151, 2005.

[22] A. B. Aguilar-Guadarrama and M. Y. Rios, "Flavonoids, sterols and lignans from Cochlospermum vitifolium and their relationship with its liver activity," Molecules, vol. 23, no. 8, p. 1952, 2018.

[23] M. Adfa, T. Yoshimura, K. Komura, and M. Koketsu, "Antitermite activities of coumarin derivatives and scopoletin from Protium javanicum Burm. f," Journal of Chemical Ecology, vol. 36, no. 7, pp. 720-726, 2010. 
[24] J. F. Sanchez, R. Entwistle, J. H. Hung et al., "Genome-based deletion analysis reveals the prenyl xanthone biosynthesis pathway in Aspergillus nidulans," Journal of the American Chemical Society, vol. 133, no. 11, pp. 4010-4017, 2011.

[25] A. L. Davis, Y. Cai, A. P. Davies, and J. R. Lewis, " ${ }^{11} \mathrm{H}$ and ${ }^{13} \mathrm{C}$ NMR assignments of some green tea polyphenols," Magnetic Resonance in Chemistry, vol. 34, no. 11, pp. 887-890, 1996.

[26] H. Lou, Y. Yamazaki, T. Sasaki et al., "A-type proanthocyanidins from peanut skins," Phytochemistry, vol. 51, no. 2, pp. 297-308, 1999.

[27] H. K. Kim, Y. H. Choi, J. S. Choi et al., "A new stilbene glucoside gallate from the roots of Polygonum multiflorum," Archives of Pharmacal Research, vol. 31, no. 10, pp. 1225-1229, 2008. 